\title{
The Carcinogenic Load of the Environment: Benzo(a)Pyrene in Sediments of Arctic Waters
}

\author{
H. F. STICH' and B. P. DUNN'
}

\begin{abstract}
Baseline levels of the chemical carcinogen benzo(a)pyrene were measured in arctic sediments. Levels were highest in samples from the Mackenzie River delta and adjacent areas of the Beaufort Sea. The distribution of carcinogen did not correspond to the location of inhabited areas - a natural rather than a man-made source for polycyclic aromatic hydrocarbons in arctic sediments is indicated.
\end{abstract}

RÉSUMÉ. Les niveaux minimum de benzo(a)pyrènes "carcinogènes", étaient mesurés chimiquement dans les sédiments arctiques. Les plus hauts niveaux venaient d'èchantillons en provenance du delta de fleuve Mackenzie et des parties adjacentes de la Mer de Beaufort.

La répartition des "carcinogènes" ne correspondait pas à la position des régions habitées; il y a une indication d'une source naturelle plutôt qu'artificielle pour les hydrocarbures aromatiques polycycliques dans les sédiments arctiques.

Traduit par Alain de Vendegies, Aquitaine Company of Canada Ltd.

\section{INTRODUCTION}

Stimulated by the possibility of oil leakage and spills, considerable attention has been given to aliphatic hydrocarbons in the arctic environment. Their geographic distribution (NAS publication, 1975; McAuliffe, 1976) and accumulation in sediments (Shaw and Cheek, 1976) has been submitted to numerous careful examinations. Less work has been done on the occurrence of polycyclic aromatic hydrocarbons (PAH) in marine environments (Neff, 1979) although many of them are potent carcinogens and thus could represent a hazard to living organisms including man (IARC, 1972). It is widely assumed that PAH's in bottom sediments and sedentary organisms are associated with human activity (Dunn and Stich, 1976; Grimmer and Bohnke, 1975; Neff, 1979). Benzo(a)pyrene [B(a)P] which is one of the carcinogenic PAH's was observed in commercial and pleasure boat harbors, vicinities of urban or industrial discharges, and piers containing creosoted pilings.

In this paper we report the occurrence of $\mathrm{B}(\mathrm{a}) \mathrm{P}$ in shore sediments of what are generally considered to be pristine arctic waters. The observed concentrations of B(a)P can be used as a baseline useful for detecting man-made contaminations. These studies may help in recognizing naturally-occurring hot spots of chemical carcinogens which remain unrecognized because of our current emphasis on man-made contamination.

\section{MATERIAL AND METHODS}

\section{Sediment Samples}

Samples were obtained by collecting the top layers of sediment not exceeding $5 \mathrm{~cm}$ in depth. The samples were frozen within an hour of collecting and only

'Environmental Carcinogenesis Unit, British Columbia Cancer Research Centre, 601 West 10th Avenue, Vancouver, B.C., Canada V5Z 1L3 
thawed prior to $\mathrm{B}(\mathrm{a}) \mathrm{P}$ analysis. The sediment was kept in plastic bags which did not contribute any detectable amounts of PAH's to the samples.

\section{Analysis of Benzo(a)pyrene}

Techniques used for the extraction of polycyclic aromatic hydrocarbons and the removal of interfering materials have been described previously (Dunn, 1976). In brief, 50-100 $\mathrm{g}$ of sediment were refluxed with alcoholic $\mathrm{KOH}$, then the sediment removed by decantation. Water was added to the alcoholic extract, and the hydrocarbons partitioned into iso-octane. Interfering materials were removed by column chromatography of Florisil and by partitioning the extract between iso-octane and DMSO. An internal standard of radioactively labelled benzo(a)pyrene was added to each sample before extraction in order to correct for losses during the procedures.

Benzo(a)pyrene was measured in one of two ways. For Alaska samples, and for Mackenzie/Beaufort Sea samples taken in 1977, benzo(a)pyrene was separated from other polycyclic aromatic hydrocarbons by thin-layer chromatography on cellulose acetate, and measured by fluorimetry (Dunn, 1976). For Mackenzie/Beaufort Sea samples taken in 1979, purified extracts of polycyclic aromatic hydrocarbons were subjected to high pressure liquid chromatography on a Perkin-Elmer HC-ODS column using a gradient of 60 to $99 \%$ acetonitrile in water. Chromatographic separations were simiar to those reported by Ogan et al. (1979). Benzo(a)pyrene was measured using a UV absorption detector and a fluorescence detector in series. When samples of sediments were split and analyzed by both methods, analytical results generally agreed to within $\pm 25 \%$. Because such analytical variability is less than the variability between different samples, no distinction is made in the tables between sediments analyzed by different procedures.

Duplicate samples of sediments were dried at $80^{\circ} \mathrm{C}$ for 24 hours to determine their moisture content. Dried samples were then heated at $500^{\circ} \mathrm{C}$ for 6 hours for determination of the ashable organic content by weight loss during ignition. Data in tables are expressed in micrograms benzo(a)pyrene per $\mathrm{kg}$ wet sediment, per $\mathrm{kg}$ dry sediment, and per $\mathrm{kg}$ organic content (determined by ignition at $500^{\circ}$ ). For example, if a $100 \mathrm{~g}$ wet sample is found to contain $1 \mu \mathrm{g}$ benzo(a)pyrene, and analysis of a duplicate sample reveals a dry weight of 50 grams and a loss during ignition of 5 grams, the contamination of the sample is $10 \mu \mathrm{g} / \mathrm{kg}$ wet weight, 20 $\mu \mathrm{g} / \mathrm{kg}$ dry weight, and $200 \mu \mathrm{g} / \mathrm{kg}$ organic content.

\section{RESULTS}

Bottom sediments were collected from areas of three geographically distinct regions: (1) Kotzebue and Nome area (Alaska); (2) Mackenzie delta and its vicinity extending westwards to Herschel Island and eastwards till Franklin Bay (Northwest Territories, Canada); and (3) Devon Island (High Arctic Canada). Most sampling sites are shown in Figures 1 and 2 . The samples were taken at the water edge during a regular low tide period. 


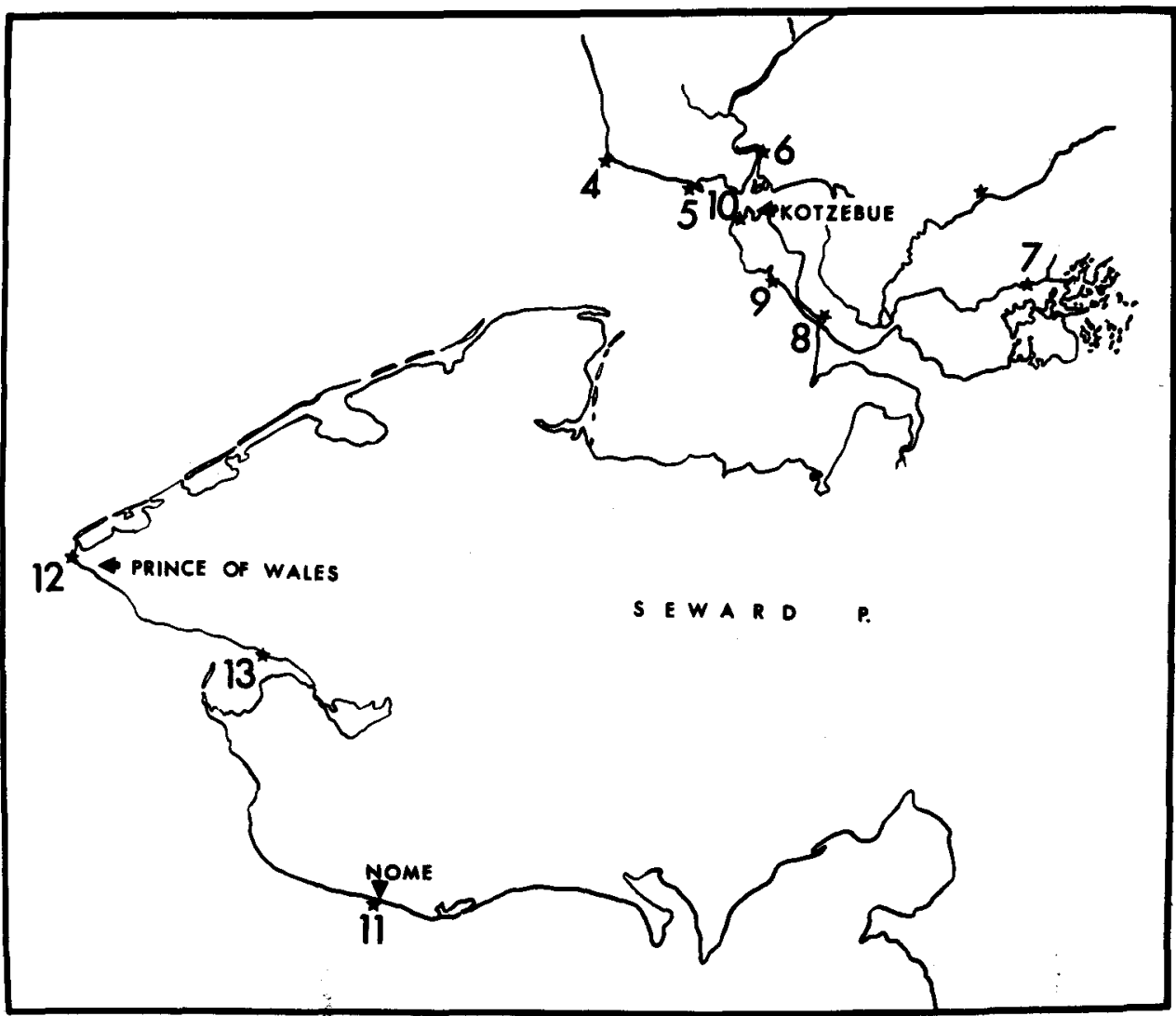

Fig. 1. Alaska study areas.

The concentrations of B(a)P per kg wet or dry sample weight are given in Table 1. When comparing the contamination of samples from a given area, it was apparent that there was to some-degree a positive correlation between levels of $\mathrm{B}(\mathrm{a}) \mathrm{P}$, and levels of organic material in the sediments. A linear regression analysis for 19 Mackenzie delta and Beaufort Sea samples taken in 1977 indicated a correlation coefficient of 0.479 (significant at the $5 \%$ confidence level). To help in the interpretation of the data, levels of $\mathrm{B}(\mathrm{a}) \mathrm{P}$ were also expressed in terms of the organic content of the samples (Table 1, last column). This latter figure gives an indication of the contamination of the organic fraction of the sediment, independent of the proportion of mineral material (sand, pebbles, etc.) in the sample. The results show considerable geographic differences in B(a)P concentrations. Relatively high concentrations were only observed in sediments of the Mackenzie delta (N.W.T.) and towards the area of the Smoking Hills (N.W.T.). Samples from Alaska and Devon Island contained low B(a)P levels.

Of particular interest is the observation that the B(a)P contents of sediments close to cities (e.g. Kotzebue and Nome in Alaska, Inuvik and Aklavik in Canada) did not show any significant increase above those found in the neighbouring areas. Similarly, the B(a)P levels of beaches with motorboat traffic (e.g. 
Table 1. Concentration of benzo(a)pyrene in marine sediments of arctic waters

\begin{tabular}{|c|c|c|c|c|c|}
\hline $\begin{array}{l}\text { Map } \\
\text { Nos. }\end{array}$ & Location & $\begin{array}{c}\text { No. of } \\
\text { Samples }\end{array}$ & $\begin{array}{c}\text { Average } \\
\text { B(a)P } \mu g / k g \\
\text { Wet Weight } \\
\end{array}$ & $\begin{array}{c}\text { Average } \\
\text { B(a)P } \mu g / k g \\
\text { Dry Wejght }\end{array}$ & $\begin{array}{c}\text { Average } \\
\text { B(a)P } \mu g / \mathbf{k g} \\
\text { Organic Conten } \\
\end{array}$ \\
\hline & ALASKA & & & & \\
\hline 4 & Cape Krusenstern & 1 & 0.02 & 0.02 & 2 \\
\hline 5 & Sheshalik & 7 & 0.03 & 0.8 & 18 \\
\hline 6 & Noatak & 2 & 0.04 & 0.65 & 10 \\
\hline \multirow[t]{2}{*}{7} & Selavik & 1 & 1.1 & 1.5 & 132 \\
\hline & Baldwin Peninsula & & & & \\
\hline 8 & Arctic Shelter Cabin & 2 & 0.4 & 1.2 & 26 \\
\hline 9 & Reindeer Corral & 1 & 0.3 & 1.0 & 4 \\
\hline 10 & Kotzebue & 2 & 0.4 & 0.5 & 34 \\
\hline 11 & Nome & 4 & 0.8 & 1.0 & 75 \\
\hline 12 & Prince of Wales & 3 & 0.3 & 0.5 & 10 \\
\hline \multirow[t]{2}{*}{13} & Teller Reindeer Station & 2 & 0.04 & 0.04 & 3 \\
\hline & \multicolumn{5}{|c|}{ NORTHWEST TERRITORIES-CANADA } \\
\hline 14 & Herschel Island & 1 & 0.5 & 0.6 & 46 \\
\hline 15 & Stoke Point & 1 & 0.5 & 0.6 & 72 \\
\hline 16 & Kay Point & 2 & 7.5 & 10.1 & 442 \\
\hline 17 & King Point & 2 & 1.9 & 2.3 & 181 \\
\hline 18 & Shingle Point & 2 & 2.4 & 3.3 & 36 \\
\hline 19 & Inuvik Channel & 2 & 5.3 & 10.0 & 113 \\
\hline 20 & Mackenzie Delta & 1 & 5.4 & 8.6 & 151 \\
\hline 21 & Mackenzie Delta & 1 & 1.8 & 2.3 & 67 \\
\hline 22 & Mackenzie Delta & 1 & 14.0 & 23.0 & 461 \\
\hline 23 & Mackenzie Delta & 1 & 20.0 & 33.1 & 539 \\
\hline 24 & Mackenzie Delta & 1 & 7.6 & 2.2 & 30 \\
\hline 25 & Aklavik & 1 & 15.6 & 25.0 & 413 \\
\hline 26 & Kittigazuit Bay & 1 & 16.7 & 22.0 & 582 \\
\hline 27 & Kittigazuit & 1 & 19.4 & 24.3 & 1637 \\
\hline 28 & Naparotalik Spit & 1 & 0.6 & 0.7 & 86 \\
\hline 29 & Tuktoyaktuk & 6 & 1.0 & 1.5 & 66 \\
\hline 30 & Hutchison Bay & 1 & 1.9 & 2.2 & 247 \\
\hline 31 & McKinley Bay & 1 & 0.2 & 0.2 & 31 \\
\hline 32 & Nicholson Point & 1 & 1.4 & 1.6 & 97 \\
\hline 33 & Wood Bay & 2 & 7.4 & 9.5 & 122 \\
\hline 34 & Maitland Point & & 3.4 & 4.9 & 64 \\
\hline 35 & Franklin Bay & 1 & 8.5 & 13.4 & 130 \\
\hline & DEVON ISLAND & & & & \\
\hline 37 & Thomas Lee Inlet & 2 & 0.3 & 0.4 & 29 \\
\hline
\end{tabular}

the Eskimo settlements at Sheshalik, Selavik or Tuktoyaktuk) were comparable to those seen in areas devoid of human activity. The B(a)P concentrations in bottom sediments of the Eskimo settlement of Tuktoyaktuk, which has an active airport, shipping activity, and large storage depots of oil drums, are considerably lower than in the Mackenzie delta (map locations \#20 to 24) or the vicinity of the Smoking Hills (map locations \#33, 34 and 35 ) which are completely devoid of human settlements. 


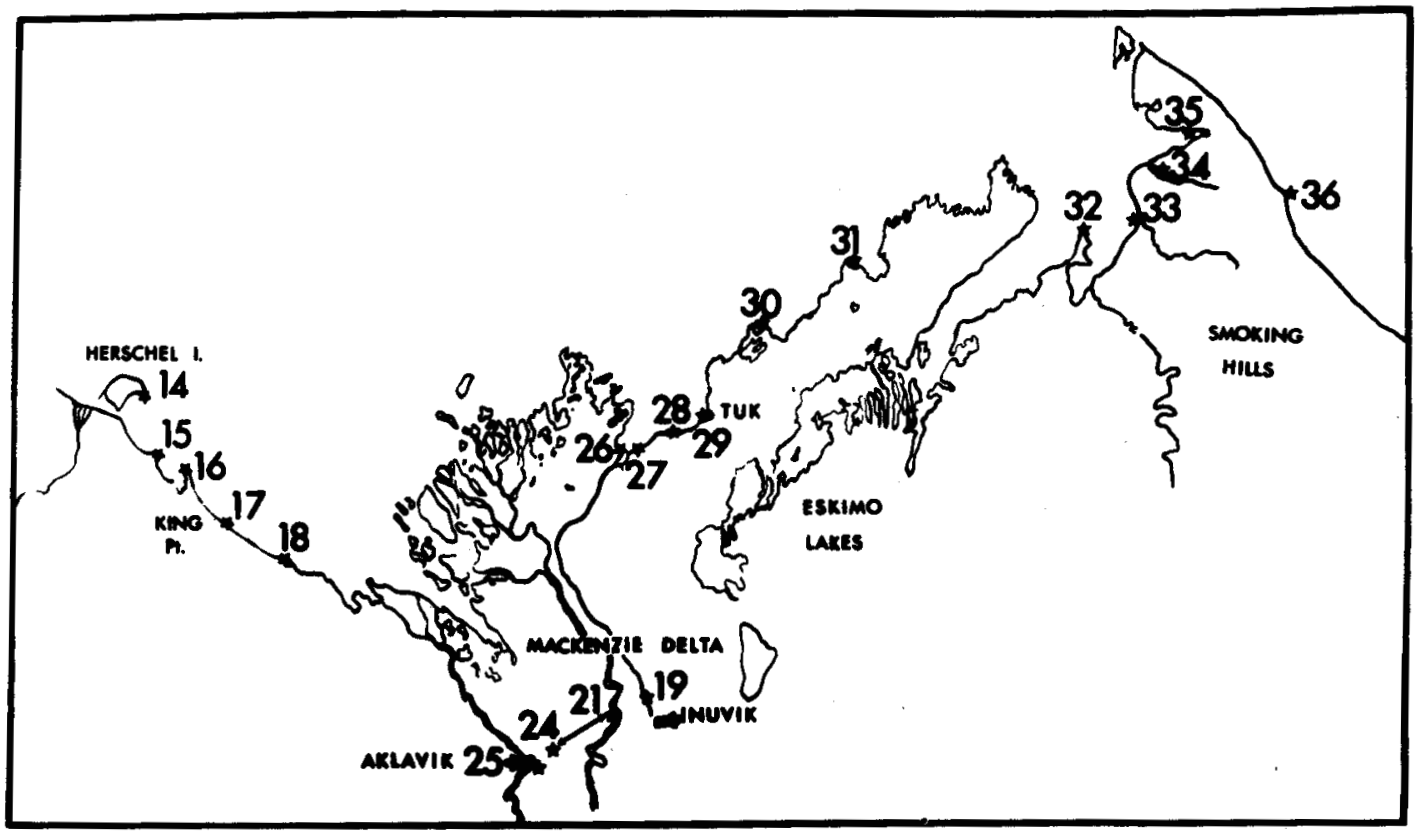

Fig. 2. Arctic Canada study areas.

Table 2. Variation of benzo(a)pyrene concentrations within a location

\begin{tabular}{llccc}
\hline Location & $\begin{array}{c}\text { Sample } \\
\text { Description }\end{array}$ & $\begin{array}{c}\text { B(a)P } \mu g / k g \\
\text { Wet Weight }\end{array}$ & $\begin{array}{c}\text { B(a)P } \mu g / k g \\
\text { Dry Weight }\end{array}$ & $\begin{array}{c}\text { B(a)P } \mu g / k g \\
\text { Organic Content }\end{array}$ \\
\hline Sheshalik & off shore, coarse sand & 0.2 & 0.2 & 22 \\
& off shore, fine sand & 0.2 & 0.2 & 27 \\
& shoreline, mud & 0.4 & 0.4 & 44 \\
& shoreline, mud with plant roots & 0.6 & 1.9 & 11 \\
& slough at shore & 0.3 & 1.0 & 6 \\
& soil at shore & 0.4 & 0.8 & 4 \\
Prince of Wales & soil at shore & 0.3 & 1.4 & 10 \\
& off shore & 0.9 & 1.1 & 25 \\
& water edge at low tide & 0.02 & 0.02 & 3 \\
& 10 m from water edge & 0.02 & 0.02 & 2 \\
& lagoon at shore & 0.2 & 0.2 & 70 \\
Tuktoyaktuk & slough with roots & 0.2 & 0.4 & 8 \\
& peninsula, fine sand & 0.1 & 0.1 & 12 \\
& city edge, fine sand & 1.2 & 1.2 & 160 \\
& city centre, fine sand & 1.1 & 1.3 & 80 \\
& city centre, black material & 2.0 & 4.4 & 17 \\
& at oil drum deposit & 0.9 & 1.0 & 49 \\
& inside harbour & 1.0 & 1.2 & 79 \\
\hline
\end{tabular}

The variation in B(a)P levels between different samples from the same sampling area is shown in Table 2 . There is considerable variability, suggesting that multiple samples are necessary to accurately assess the level of contamination in a given area. At the same time, it was found that the range of concentration in the 
Table 3. Concentration of benzo(a)pyrene in marine sediments taken in 1977 and 1979

\begin{tabular}{lllccc}
\hline Location & & Time & $\begin{array}{c}\text { B(a)P } \mu g / k g \\
\text { Wet Weight }\end{array}$ & $\begin{array}{c}\text { B(a)P } \mu g / k g \\
\text { Dry Weight }\end{array}$ & $\begin{array}{c}\text { B(a)P } \mu g / k g \\
\text { Organic Content }\end{array}$ \\
\hline \multirow{3}{*}{ Tuktoyaktuk } & inside harbour & 1979 & 1.0 & 1.2 & 79 \\
& inside harbour & 1977 & 1.3 & 1.8 & 107 \\
\multirow{3}{*}{ Beluga Point } & off shore & 1979 & 0.5 & 0.7 & 86 \\
& off shore & 1977 & 0.2 & 0.2 & 23 \\
& & 1979 & 17.1 & 22.9 & 398 \\
& east channel & 1977 & 14.0 & 23.0 & 461 \\
& east channel & 1979 & 11.6 & 22.0 & 179 \\
& West channel & 1977 & 20.6 & 33.1 & 539 \\
\hline
\end{tabular}

most contaminated sites and the least contaminated sites did not overlap single samples may therefore be useful in a preliminary assessment of the contamination of an area. Three locations were sampled both in 1977 and in 1979. The analytical results (Table 3) indicate that within the limitations imposed by sample variability there were no changes in the $\mathrm{B}(\mathrm{a}) \mathrm{P}$ content of the sediments within this period.

For comparative purposes, levels of benzo(a)pyrene in sediment samples taken from harbour and non-harbour sites outside the Arctic are shown in Table 4. Median values rather than means are used, since occasional extremely high contamination levels are encountered in harbour areas near sources of pollution, and these values have a disproportionate effect on mean values of contamination. In 20 samples taken from 9 separate non-harbour sites on the Pacific Coast of North America (Oregon to British Columbia), the median value of contamination by benzo(a)pyrene was only $0.4 \mu \mathrm{g} / \mathrm{kg}$. This value is comparable to levels found in Alaskan sediments and Devon Island samples, but is considerably less than levels encountered in sediments from the Mackenzie River and Beaufort Sea areas (median value $4.4 \mu \mathrm{g} / \mathrm{kg}$ for 22 sites in Table 1). This difference is not due to any difference in the organic content of Pacific samples compared with Arctic samples. Although the levels in the Mackenzie and Beaufort samples are higher than the baseline levels seen elsewhere, they are still considerably less than the levels which are commonly encountered in polluted areas such as harbours (Table 4). Contamination in these latter areas probably results from a combination of petroleum discharges, urban runoff and sewage discharges, fallout from urban air pollution, and leaching of creosote from treated pilings used in wharf structures.

\section{DISCUSSION}

PAH's in marine and freshwater environments originate from a great variety of different sources (Neff, 1979; Shabad, 1973). A sharp gradient of B(a)P towards a sewage treatment plant (Dunn and Stich, 1976), a higher concentration of $\mathrm{B}(\mathrm{a}) \mathrm{P}$ at the settled northern shore of the Ploner Sea than at the non-inhabited 
Table 4. Concentration of benzo(a)pyrene in harbour and non-harbour areas

\begin{tabular}{|c|c|c|c|c|}
\hline Location & $\begin{array}{l}\text { No. of } \\
\text { Samples }\end{array}$ & $\begin{array}{c}\text { Median } \\
\text { B(a)P } \mu g / k g \\
\text { Wet Weight }\end{array}$ & $\begin{array}{c}\text { Median } \\
\text { B(a)P } \mu g / \mathbf{k g} \\
\text { Dry Weight }\end{array}$ & $\begin{array}{c}\text { Median } \\
\mathrm{B}(\mathrm{a}) \mathrm{P} \mu \mathrm{g} / \mathrm{kg} \\
\text { Organic Content }\end{array}$ \\
\hline
\end{tabular}

Pacific Coast, North America

9 sites, non-harbour

Pacific Coast, North America

9 sites, harbour

Hakodate Harbour, Japan

Hong Kong Harbour

Wilhelmshaven Harbour, Germany

Wet Weigh

Dry Weight

Vancouver Harbour, Canada

$\begin{array}{rrcc}20 & 0.4 & - & - \\ 22 & 105 & - & - \\ 14 & 3 & 6.7 & 91 \\ 3 & 34 & - & - \\ 13 & 19 & 24 & 1435 \\ 9 & 200 & 288 & 7321\end{array}$

southern shore (Grimmer and Bohnke, 1975), an increase of B(a)P in core samples of recent origin (Müller et al., 1977; Hites et al., 1977) indicate an anthropogenic origin of PAH's.

There was a significant positive correlation between levels of organic material in sediments, and levels of benzo(a)pyrene. Means et al. (1979) have indicated that the absorptive properties of sediments for polycyclic aromatic hydrocarbons depend mainly on their organic carbon content. A positive correlation between organic content and B(a)P levels in sediments could result from the ability of organic material in sediments to remove B(a)P from the water column. Alternatively, B(a)P and sediment organic material might originate from the same basic source, and be found in association with each other.

The relatively high concentrations of $\mathrm{B}(\mathrm{a}) \mathrm{P}$ in bottom sediments of the Mackenzie delta, the neighbouring shores of the Beaufort Sea and the vicinity of Smoking Hills (N.W.T.) do not fit this pattern. It is difficult to trace this contamination to a man-made activity. There is no increase of $\mathrm{B}(\mathrm{a}) \mathrm{P}$ in the vicinity of small cities or settlements as seen in the case of Nome, Aklavik, Inuvik and Tuktoyaktuk. Oil seepage could conceivably be an important factor. However, high pressure liquid chromatograph fingerprint patterns of polycyclic aromatic hydrocarbons from Athabasca tar sands differ considerably from those from bottom sediments of the Mackenzie delta (unpublished results). At present we consider forest fires or tundra fires (Wein, 1976) as the most likely source of $\mathrm{B}(\mathrm{a}) \mathrm{P}$ in the marine sediments of arctic waters. There seems to be little doubt that forest and grass fires are a natural pyrolytic source of atmospheric PAH (Youngblood and Blumer, 1975; Farrington and Meyers, 1975; Suess, 1976). A relatively high concentration of $\mathrm{B}(\mathrm{a}) \mathrm{P}$ in prehistoric layers of permafrost soil also indicates a natural origin of PAH's (Jenitsky et al., 1979). However, an anthropogenic source cannot be completely excluded considering that PAH's can be carried over long distances (Bjorseth et al., 1979). 


\section{REFERENCES}

BJORSETH, A. LUNDE, G. and LINDSKOG, A. 1979. Long-range transport of polycyclic aromatic hydrocarbons. Atmospheric Environment 13: 45-53.

DUNN, B.P. 1976. Techniques for determination of benzo(a)pyrene in marine organisms and sediments. Environmental Science and Technology 10: 1018-1021.

and STICH, H.F. 1976. Monitoring procedures for chemical carcinogens in coastal waters. Journal of the Fisheries Research Board of Canada 33: 2040-2046.

FARRINGTON, J.W., and MEYERS, P.A. 1975. Hydrocarbons in the marine environment. In: Eglinton, G. (ed.). Environmental Chemistry, Vol. 1. London: The Chemical Society. 109-136.

GRIMMER, G. and BOHNKE, H. 1975. Profile analysis of polycyclic aromatic hydrocarbons and metal content in sediment layers of a lake. Cancer Letters 1: 75-84.

HITES, R.A., LAFLAME, R.E. and FARRINGTON, J.W. 1977. Sedimentary polycyclic aromatic hydrocarbons: The historical record. Science 198: 829-831.

IARC Monographs on the Evaluation of Carcinogenic Risk of Chemicals to Man. 1972. Vol. 3.

JENITSKY, A.P., VINOGRADOV, V.N., RIABCHUN, V.K. MISHENKO, V.S., GVILDIS, V.I., CHERNENKII, B.I., BELITSKII, G.A. and SHABAD, L.M. 1979. Analysis of prehistoric levels of benzo(a)pyrene in permafrost soil. Akademiia Nauk SSSR Doklady. Novaia seriia 245: 254-257.

McAULIFFE, C.D. 1976. Surveillance of the marine environment for petroleum hydrocarbons. In: Wood, D. W., and Burrell, D.C. (eds.). Assessment of the Arctic Marine Environment. Fairbanks: University of Alaska. 403-423.

MEANS, J.C., HASSETT, J.J., WOOD, S.G. and BANWART, W.L. 1979. Sorption properties of energy-related pollutants and sediments. In: Jones, P.W., and Leber, P. (eds.). Polynuclear Aromatic Hydrocarbons. Ann Arbor: Ann Arbor Science Publishers. 327-340.

MÜLLER, G., GRIMMER, G. and BOHNKE, H. 1977. Sedimentary record of heavy metals and polycyclic aromatic hydrocarbons in Lake Constance. Naturwissenschaften 64: 422-431.

National Academy of Sciences. 1975. Petroleum in the Marine Environment, Washington, D.C.

NEFF, J.M. 1979. Polycyclic Aromatic Hydrocarbons in the Aquatic Environment. London: Applied Science Publishers.

OGAN, K., KATZ, E. and SLAVIN, W. 1979. Determination of polycyclic aromatic hydrocarbons in aqueous samples by reversed-phase liquid chromatography. Analytical Chemistry 51: 13151320.

SHABAD, L.M. 1973. Carcinogens Circulation in the Environment. Moscow: Medicina.

SHAW, D.G. and CHEEK, L.M. 1976. Hydrocarbon studies in the benthic environment at Prudhoe Bay. In: Wood, D.W., and Burrell, D.C. (eds.). Assessment of the Arctic Marine Environment. Fairbanks: University of Alaska. 425-431.

STICH, H.F., ACTON, A.B., DUNN, B.P., OISHI, K., YAMAZAKI, F., HARADA, T., PETERS, G. and PETERS, N. 1977. Geographic variations in tumor prevalence among marine fish populations. International Journal of Cancer 20: 780-791.

SUESS, M.J. 1976. The environmental load and cycle of polycyclic aromatic hydrocarbons. Science of the Total Environment 6: 239-250.

WEIN, R.W. 1976. Frequency and characteristics of arctic tundra fires. Arctic 29: 213-222.

YOUNGBLOOD, W.W. and BLUMER, M. 1975. Polycyclic aromatic hydrocarbons in the environment: Homologous series in soils and recent marine sediments. Geochimica Cosmochimica Acta 39: 1303-1314. 